\title{
PROBLEMS FACED BY STUDENTS IN LEARNING MICROECONOMICS COURSE
}

\author{
Nusaila Johari, Dayana Farzeeha Ali*, Tono Hassan, Mahani Mokhtar, Nur Husna Abdul Wahid, \\ Muhammad Khair Noordin, Nor Hasniza Ibrahim \\ Universiti Teknologi Malaysia, Johor Bahru, Malaysia \\ *dayanafarzeeha@utm.my
}

\begin{abstract}
Teaching and Learning (T\&L) methods in the present days need to be creative and diverse in order to produce quality graduates. Memorization method will produce students who are unable think critically since they are regimented to memorize facts only. It may cause students easier to forget the contents when there is a disturbance during the memorization process. One of the courses that need attention to encounter this problem is Microeconomics. Based on a preliminary study, it was found that students had problem to master Microeconomics. Therefore, this study was conducted to identify problems faced by students who enrolled in a Microeconomics course at a local Malaysian university. Results of the study found that the course was challenging for students to master since they had low visualization skill. Therefore, it was difficult for the students to visualize complex graphs and interpret data in the graphs.
\end{abstract}

Keywords: TVET, Microeconomics, Visualization Skill, Teaching and Learning

\section{INTRODUCTION}

\section{Technical and Vocational Education (TVET)}

In line with the sixth challenge of Vision 2020, Malaysia intends to create a scientific and progressive society, a community with high-power of technologies and people who are not only technologists but also contribute to future scientific and technological development. Therefore, Malaysian education system needs to be improved to develop a knowledgeable, critical and creative thinking generation, as well as people who possess leadership skills and able to communicate with the whole world. Technical and Vocational Education (TVET) is one of the educational and curriculum fields which needs to be improved. Visualization skills play important role in TVET because it involves the process of thinking using images (Atan \& Tasir, 2008). However, TVET students face difficulties in mastering this skill (Noorasura \& Sazilah, 2011). These issues need to be solved since acquisition of visualization skills are often associated with success and achievement, especially in technical and vocational education, engineering, science and other fields (Ali \& Mokhtar, 2014). According to Chen (2006), visualization skills are important in increasing students' cognitive level. However, visualization skills are getting less attention and less emphasized in Teaching and Learning (T\&L) (Hegarty, 2014). This is because Malaysian system of education is exam-oriented. Thus, completion of syllabus is detrimental to ensure success in examination. As a result, students have difficulties to acquire this skill (Noorasura \& Sazilah, 2011). Microeconomics is one of the courses which requires visualization skills. This is because, this course requires students to be good in mathematical skills and also possess the ability in drawing graphs as well as convert the graphs to data and text and vice versa (Hegarty, 2014). This course is a compulsory course for majority of students who are taking Bachelor in Economics, Business Management and Finance.

\section{Microeconomics}

Microeconomics is a compulsory course taken by most students enrolled in Economic, Business Management and Finance faculty. Microeconomics is a subject that requires student to understand topics such as Demand and Supply Market, Market Structure and Economic theory. It is a vocational course which requires students to use their visualization skills since this course has a lot of graphs where students need to draw, convert data into text and graph and vice versa. Microeconomics can be a difficult course by majority of students (Zulkifli \& Azizi, 2017). This course demands combination of 
few skills such as understanding or memorizing concepts, mathematical skills, graphs drawing, application of theory and problem-solving skill. Microeconomics requires students to be good in critical analysis, thinking and also visualization skill. According to Saud and Foong (2006), weak students in quantitative literacy will contribute to low achievement in economic literacy. In addition, students must also be able to explain complex ideas logically and fluently.

Students who face problems with basic statistical skills and mathematical skills will have difficulties to draw and interpret the graphs which will reflects on their achievements in microeconomics subjects (Schuhmann et al., 2005). A lot of studies were conducted by researchers worldwide to identify factors which influences students' achievement in the economic subjects. Most of them found out that achievement of students in mathematical subjects had great influence towards their achievements in economic subjects. However, there is lack of study being conducted in Malaysia regarding problems faced by students in learning Microeconomics and solution to the problem especially in the context of higher learning.

\section{Visualization Skills}

Nowadays, there are various issues regarding the importance and requirements of possessing visualization skills in education (Atan \& Tasir, 2008). Visualization is an important skill that can increase students' cognitive level (Chen, 2006) and students' quantitative literacy (Saud \& Foong, 2006), Visualization skill does not solely focus on memorization of facts, instead it focuses more on the deeper understanding of a concepts in which they can relates with the real-world concepts. Data visualization is a type of visualization needed in Microeconomics subject. Data visualization is the skills that involves the creation and representation of data in visual forms. Examples of the implementation of this skill is converting raw data into graphs that enable users to present the data in a more interactive and less difficult manner. Having this skill will help improve students' skills in imagination, drawing graphs and visualizing techniques to convert graphs into data and vice versa. Students with poor visualization skills will not be able to perform these tasks efficiently. This is because, most graduates are unable to apply abstract economic concepts with real environment and often face difficulties interpret and make explanation using data. Therefore, it will be hard for them to execute any job-related tasks.

During learning process, students need to visualize what they learn through three processes namely memory, imagery and knowledge in which it is considered as a complex process. Many studies have shown that visualization skills are crucial in helping students to master complex concepts and help them further understand the phenomenon of their learning environment (Ali \& Hussin, 2016; Saforrudin, 2016). In regard to this, visualization skills should be given more attention in vocational education, since it has proven to be a factor in determining individuals' intelligence. Therefore, this study was conducted to examine problems faced by students in Microeconomic courses (Johnston et al., 2000; Khalid, 2012).

\section{METHODOLOGY}

This study investigated problems faced by students in learning Microeconomics course. This study applied both quantitative and qualitative method which involves document analysis and interview protocol. Quantitative method in this study involves a document analysis done on students' examination result on Microeconomics subjects while qualitative method involved a semi-structured interview conducted among Microeconomics lecturers. Quantitative data obtained from this study were then analyzed using descriptive statistics while Qualitative data were analysis using Thematic Analysis.

\section{RESULTS AND ANALYSIS}

Table 1 shows the distribution of grades acquired by students in their examination in Microeconomics at a local Malaysian university for the months of May 2006, June 2015, December 2015 and June 2016. 
Table 1. Students' examination results based on percentage (Source: Examination record in Malaysian local universities (2016))

\begin{tabular}{|c|c|c|c|c|}
\hline \multirow{2}{*}{ Grades } & \multicolumn{4}{|c|}{ Semesters } \\
\cline { 2 - 5 } & May 2006 & June 2015 & Dec 2015 & June 2016 \\
\hline A & 14.19 & 25.54 & 21.87 & 28.36 \\
\hline B & 58.16 & 29.82 & 34.11 & 21.25 \\
\hline C & 22.17 & 22.45 & 28.32 & 26.17 \\
\hline Fail & 5.48 & 22.19 & 15.7 & 24.22 \\
\hline
\end{tabular}

Based on the document analysis conducted in this study, Microeconomics course remains to be a difficult course among students over the last decade. Students' achievement in 2006 showed that 58.16 percent of the students received grade B and 22.17 percent received grade C. Meanwhile, 5.48 percent of the students failed and had to repeat the course. Table 1 also shows that majority of the students in 2015 and 2016 had obtained grade B and C while the percentage of students who failed this course was in between $15.7 \%$ to $24.22 \%$.

Students mostly have difficulties in understanding economics concept due to their lack of visualization skills. Visualization skills are not being emphasized in teaching and learning process at Malaysian universities due to the exam-oriented system of Malaysian Education System which has prompted lecturers to focus only on completing the syllabus. Therefore, lecturers do not spend an adequate time in teaching and enhancing students' visualization skills. However, this will only lead to low visualization skills among students which will affect their understanding towards this subject as well as influence their examination result.

Table 2. Problem faced by students in learning microeconomics course

\begin{tabular}{|c|c|c|c|}
\hline & Respondent 1 & Respondent 2 & Respondent 3 \\
\hline \multicolumn{3}{|c|}{ Common Problem Faced When Learning Microeconomic } \\
\hline Basic mathematical and statistical skills & $/$ & $/$ & $/$ \\
\hline Memorizing without understanding concept & $/$ & $/$ & $/$ \\
\hline $\begin{array}{c}\text { Imagine, draw, and convert data to graphs and } \\
\text { vice versa }\end{array}$ & $/$ & $/$ & $/$ \\
\hline Data interpretation & $/$ & $/$ & $/$ \\
\hline Applying economic concept in certain situation & Difficult Topic & $/$ & \\
\hline Market Structure & $/$ & $/$ & \\
\hline Dheory on Cost and Production & $/$ & $/$ & \\
\hline Elasticity on Demand and Supply & $/$ & $/$ \\
\hline Donopolistic Competition & $/$ & \\
\hline Oligopoly & Sub-Topic & \\
\hline
\end{tabular}




\begin{tabular}{|c|c|c|c|}
\hline $\begin{array}{c}\text { Determinants of Elasticity of Demand and } \\
\text { Supply }\end{array}$ & & $/$ & \\
\hline Economic and Diseconomic of Scales & $/$ & $/$ & \\
\hline
\end{tabular}

Based on the data shown in Table 2, there are five main problems that have been identified from the interview. From the table, all respondent agreed that students faced problem in learning Microeconomics course due to their inability to perform basic mathematical and statistical tasks. If students do not master basic mathematical and statistical skills, they will have problems in quantitative literacy. Quantitative literacy is a basic skill that students need to master because this course has mathematic and statistic requirement. Other than that, all respondents also agreed that they have problems in imagining, drawing and converting the data to graphs and vice versa as well as interpreting the data. These two problems are closely related to the data visualization skills. Other than that, majority of lecturers also mentioned about students' problems in memorizing and understanding concept as well as applying economic concept in certain situation.

Apart from the previous findings, it is also found that market structure is the most difficult topics in Microeconomics course. Students also seems to face difficulties when learning elasticity on demand and supply as being claimed by two out of three respondents. The least difficult topics is theory on cost and production where only one respondent agreed that this course is difficult for the students to understand. Next, respondents also are asked about the sub-topics that students have problems with throughout the course. Through the interview, it is found that respondents agreed that monopolistic competition and oligopoly is the hardest topic among all the sub-topics in microeconomics course. All three respondents identified these two topics as the most difficult sub-topics among students in this course. Thus, it is proven from the interview session that there are indeed some issues among problem when learning microeconomics course especially in terms of the data presentation in the forms of visual representations.

\section{DISCUSSION}

Since there is a lot of study focusing on Technical and Engineering, this study explores on Vocational Education specifically in Microeconomic. Furthermore, this study found Microeconomic as most of difficult subject in Economic, Business Management and Finance faculty and it is supported by the study done by Zulkifli and Azizi (2017). This is compulsory course for those faculty students. Therefore, these studies are trying to determine the reason why student are facing difficulty to mastering this course.

Based on the findings, it is found that the problems in Microeconomic course has continued over the last decade. If the problem continuously persists, university will end up producing non-quality graduates. Based on above result, one of the reasons is because students are facing difficulties to understand economic concept. This result is parallel to a study done by Yin (2008). Students are only being exposed to certain concepts, but the method on how to apply them in certain situations is not being emphasized by educators. As a result, student will remember the concept and fact without fully understanding the basic concept. This learning process is less efficient because once there are any disturbances during learning process, it will make it easier for them to forget. Memorization only produces students who remember facts for a short-term period and it is easily for them to forget the facts if there is any disturbance during the process. As a result, students are less likely to think well and this will affect their cognitive level. Visualization skills is one of the skills that can help students in increasing their cognitive level (Chen, 2006) and also understand the abstract economic concept. Therefore, visualization skill is really important in Microeconomic course because it requires students to use a lot of data, graph and economic abstract concept.

These studies also found that students had problem in learning in Microeconomics course because of their basic mathematical and statistical skill is low. If students do not master basic mathematical and statistical skills they will be weak in quantitative literacy and as a result their achievement in economic literacy will be low. Students with the above described circumstances will have difficulty to draw graphs and interpret the graphs (Saud \& Foong, 2006). Subsequently, it will influence students' 
understanding because their inability to imagine and draw graphs will make them difficult to visualize how to convert graphs to data and vice versa. Thus, visualization skill can help students to increase their quantitative literacy. In the economics course, students need visualization skill because there are lots of graphs and data which require students to imagine, draw, and convert data to graphs and vice versa.

At the same time, visualization skill able to help student in increasing students' imagination so that student be able to draw the graph, imagine the graph and visualize how to convert graph to data and vice versa. Students with poor visualization skills will not be able to perform efficiently when they are working in industries. Inability to interpreted data also being one of a most common problem facing by student's in learning Microeconomics. Failure to interpret data will cause them inability to master this course. Other than that, student's also faced difficulties to apply economic concept in certain situation. Students with poor visualization skills will not be able to perform efficiently when they are working in industries. Students who cannot apply abstract economic concepts with real environment and have difficulty to tell stories using data, will not be able to execute any job-related tasks. Therefore, mastery of visualization skills is essential to be emphasized at university level. The interview also focuses on the difficult topic and sub-topic in Microeconomics Courses. Based on the result given, Market Structure is the most difficult topic that facing by student. In this topic, the common problem comes from Monopolistic Competition and Oligopoly. Based on the syllabus of this course, it is found that this sub-topic consists of a lot of graph and student need to imagine, draw, interpret, and convert data to graphs and vice versa. The sub-topic involve is Economic and Diseconomy of Scales under Elasticity on Demand and Supply also the one of most difficult on this course.

\section{CONCLUSION}

Students who enroll in programs such as Economics, Business Management and Administration, Accountancy and Finance need to possess high cognitive and visualization skills. Results from this study showed that the main cause of the problem was due to students' low level of visualization skills. In addition, memorization of facts eventually leads to students' inability to understand concepts and its application in certain situations. Students also had difficulties to visualize the methods to draw, convert and interpret graphs to data and texts and vice versa. Thus, it is important to emphasize more on visualization skills during teaching and learning to improve students' ability to understand this course. By emphasizing more on visualization skills, educators also can improve cognitive power of students to make it easier for them to understand abstract economics concepts. Other than that, it can also help students to deal with a lot of data and graphs which require students to draw, imagine and convert data to graph and vice versa. These tasks can be easily achieved if students have good visualization skills. Apart from that, visualization skills can enhance students' creativity and synthesis skills indirectly so that they will not encounter any problems once they enter the job market. This is why training of visualization skills needs to be emphasized at university level in order to produce a quality graduates, especially in Economics, Business Management and Administration, Accountancy and Finance field.

\section{ACKNOWLEDGEMENTS}

The work described in this paper was supported by Research University Grant Scheme under Universiti Teknologi Malaysia Tier 1 (Q.J130000.2531.19H10).

\section{REFERENCES}

Ali, D. F., \& Hussin, M. N. K. (2016). Spatial visualization ability among engineering students in Malaysia. Man in India, 96(1), 203-209.

Ali, D. F., \& Mokhtar, M. (2014). Visualization skills among Universiti Teknologi Malaysia student. In IEEE International Symposium on Technology Management and Emerging Technologies, pp. 139-142. Atan N. A. \& Tasir Z. (2008). Visualisasi menerusi sistem berasaskan pendekatan pembelajaran situasi dalam persekitaran autentik dalam mempelajari rekabentuk infrastruktur rangkaian komputer bagi program perguruan, In 2nd International Malaysian Educational Technology Convention, pp. 259-269. Chen, C. J. (2006). The design, development and evaluation of a virtual reality based learning environment. Australasian Journal of Educational Technology, 22(1), 39-63. 
Hegarty, M. (2014). Spatial thinking in undergraduate science education. Spatial Cognition and Computation, 14(2), 142-167.

Johnston, C. G., James, R. H., Lye, J. N., \& McDonald, I. M. (2000). An evaluation of collaborative problem solving for learning economics. Journal of Economic Education, 31(1), 13-29.

Khalid, M. (2012). Faktor-faktor mempengaruhi motivasi pembelajaran terhadap subjek ekonomi mahasiswa Universiti Kebangsaan Malaysia Fakulti Pendidikan.

Noorasura, A. D., \& Sazilah, S. (2011). A model of mobile learning object design for concept comprehension using reciprocal teaching strategies and augmented reality. In IEEE International Conference on Computer Science and Automation Engineering, pp. 717-720.

Saforrudin, N. (2016). Konsep penggunaan aplikasi luasan realiti (AR) dalam pendidikan. In 4th Global Summit on Education, pp. 14-15.

Saud, M. S., \& Foong, L. M. (2006). Kemahiran visualisasi: Kemahiran kognitif tahap tinggi dalam pendidikan teknik dan vokasional. In Seminar Kebangsaan Pendidikan Teknik dan Vokasional, pp. 1-12. Schuhmann, P. W., McGoldrick, K., \& Burrus, R. T. (2005). Student quantitative literacy: Importance, measurement, and correlation with economic literacy. The American Economist, 49(1), 49-65.

Yin, K. Y. (2008). Keberkesanan kaedah penyelesaian masalah secara kolaboratif dalam kalangan pelajar ekonomi tingkatan enam. Phd thesis, Universiti Sains Malaysia.

Zulkifli, N., \& Azizi, S. N. A. (2017). Faktor kelemahan pelajar dalam mata pelajaran ekonomi asas di peringkat SPM di sekolah-sekolah terpilih di negeri Johor. In World Conference on Integration of Knowledge, pp. 127-134. 